\title{
The study of changes in the land fund balance to manage the sustainable spatial development of the developed and developing territories in Russia
}

\author{
Alexander Sizov*
}

Moscow state University of geodesy and cartography, Gorokhovsky per., 4, 105064Moscow, Russia

\begin{abstract}
The analysis of changes in the land fund balance reflects the implementation of the scientific paradigm - "minimum initial information maximum valid generalizations". Active indicators, namely the shares of different types of land in the composition of certain land categories from the total area of a certain land category should be a priority. In 2011-2017, the share of settlement lands in the total land fund in the Russian Federation increased from $1.15 \%$ to $1.19 \%$, industrial and other specialpurpose lands - from $0.99 \%$ to $1.02 \%$, which corresponds to modern Russian ideas about the spatial, but extensive, development of territories. The rate of change in the shares of different lands from the area of lands of different categories, \%/year, is proposed to use an integrating estimated indicator for the spatial development of territories. The share of agricultural lands in the Russian Federation was increasing in the composition of settlement and industrial lands at a rate of $0.03 \% / y e a r$, which indicates their degradation. The share of forest lands decreased in the composition of industrial lands $(-0.09 \% /$ year). These lands served as a "source" of new farming lands for agricultural lands. In the settlement and industrial lands, the share of building land was increasing $(0.06 \% /$ year), while the share of land under roads was decreasing (from -0.03 to $0.05 \% /$ year) due to their unbalanced development. Disturbed lands also need their intensive reclamation.
\end{abstract}

\section{Introduction}

The search for criteria for a proper analysis of the results of the spatial development of territories determines the relevance of the research. We have found that the spatial development of territories can be diagnosed by calculating the value of their environmentforming potential, which functionally depends on the balance of land funds in a particular territory [1]. The objective of the research was to clarify the possibilities of methods for analyzing the system of statistical information to characterize the results of the spatial development of territories and to improve quantitative methods for calculating indicators related to assessing the state and use of lands.

\footnotetext{
*Corresponding author: ap sizov@mail.ru
} 
During the last five years, the promising goal of land and property regulation has fundamentally changed in Russia, which is currently formulated as ensuring the comprehensive sustainable development of the state, according to A.G. Dugin, on the fundamental basis of digital spatial information. The reason for the changes is in the need to strengthen the national statehood, driven by a decline in the provincials.

The definitions of "spatial development" are quite common, although its content varies significantly in different sources [2, 3]. Art. 46.1 of the Town Planning Code of the Russian Federation is devoted to the development of developed areas [4]. Spatial development provides an increment of appropriate indicators across the country. It should not be limited in the space-time continuum.To improve state planning, the European Charter for Regional Planning was approved as an important source for the formulation of topics for further international research and the basis for listing the principles of sustainable spatial development for Europe. The Charter introduced the concept of "spatial planning", which made it possible to formalize the achievement of territorial planning goals in the XXI century, using modern IT technologies in spatial data [5]. Different countries achieve goals considering their national scientific and informational traditions.

Russia keeps a centralized approach to planning. The urbanization process promotes the development of the geographic foundations of nature management in the "country of cities" and the role of urban planners. Therefore, urban planning regulation should be based on the principles of environmentally-focused nature management [6]. Meanwhile, our country abides a unified, environmental-based approach to the development of territories.

\section{Materials and Methods}

Our content of the spatial development of territories includes the necessary activities of the state bodies of Russia, carried out at various levels of spatial planning, and ultimately forming the national geo-economic space. We have formulated conceptual provisions of spatial development [7].

Spatial development can be either extensive (for example, accommodate an increasing number of urban residents by increasing the area of building land with a constant number of stories in buildings), and intensive (accommodate an increasing number of urban residents by increasing the number of stories of buildings with a constant or even decreasing area of the developed lands). The system of a comprehensive assessment of the condition and use of land consists of indicators for assessing the quality of land, the efficiency of their use concerning changes in the environment-forming potential of territories, cadastral appraisal, and collection of land fees.

The development of territories differs based on the categories of land.

The "physical" result of spatial planning is a change in the balance of the land fund (by category or by land). Usually, the absolute area of building land increases, while the area of agricultural and forest land tends to decrease. In specific situations, other options are possible, but in any case, for a certain technological paradigm, an optimal balance of lands, stable for a more or less long period, is achieved. An abrupt change in the balance of lands is associated, in most cases, with a change in the next technological paradigm.

We propose to divide indicators of changes in the land fund balance into two groups:

- "passive" indicators - changes in the shares of certain categories and types of land from the total area of the territory for a certain period; and

- "active" indicators - changes in the shares of certain types of land in a separate category of land from the total area of this land category for a certain period (another possible, but the less informative approach is to calculate the share of land of certain categories in a particular type of land from the total area of this type of land). 
We used the methods of information-logical analysis in the subject area of land use and direct counting. Based on the postulate, which provides the maximum number of generalizations with a minimum amount of initial information, the author interprets the results for which the data of the Federal Register for the Russian Federation were taken. We have already tested this approach in the study of the results of state land supervision in the Russian Federation [8]. We have analyzed the dynamics of "active" indicators at the level of the Russian Federation as a whole for 2011-2017. The initial representative information on the balance of land fund in the format of land distribution by the two most dynamically changing categories was prepared according to the current publicly available data of Rosreestr [9].

\section{Results and Discussion}

Changes in the absolute areas of lands of various categories and lands (units of area) are inconvenient for assessing the dynamics of the balance. For this purpose, relative indicators suit better (specific, per unit area, expressed in fractions of a unit, or percent) (Tables 1, 2)

Table 1. Changes in the shares of different lands from the settlement land area (\%)

\begin{tabular}{|c|c|c|c|c|}
\hline Lands & $\mathbf{2 0 1 1}$ & $\mathbf{2 0 1 5}$ & $\mathbf{2 0 1 7}$ & Result \\
\hline Agricultural & 47.54 & 47.57 & 47.69 & increase: $\uparrow$ \\
\hline Forest lands & 10.14 & 10.23 & 10.17 & $\sim$ const \\
\hline Building lands & 17.81 & 18.16 & 18.17 & increase: $\uparrow$ \\
\hline Roads & 9.65 & 9.39 & 9.36 & decrease: $\downarrow$ \\
\hline Disturbed lands & 0.49 & 0.48 & 0.48 & $\sim$ const \\
\hline
\end{tabular}

Table 2. Changes in the shares of different lands from the industrial land area (\%)

\begin{tabular}{|c|c|c|c|c|}
\hline Lands & $\mathbf{2 0 1 1}$ & $\mathbf{2 0 1 5}$ & $\mathbf{2 0 1 7}$ & Result \\
\hline Agricultural & 6.51 & 6.63 & 6.69 & increase: $\uparrow$ \\
\hline Forest lands & 24.45 & 23.96 & 23.93 & decrease: $\downarrow$ \\
\hline Building lands & 5.32 & 5.52 & 5.66 & increase: $\uparrow$ \\
\hline Roads & 10.70 & 10.56 & 10.53 & decrease: $\downarrow$ \\
\hline Disturbed lands & 2.19 & 2.35 & 2.40 & increase: $\uparrow$ \\
\hline
\end{tabular}

The rationale for the situation with not too large but stable changes is as follows. The balance of the land fund, both by category and by land, in such a large country, as the Russian Federation, is quite stable, and had to be that way, as a significant part of the territory is practically not used in economic activities. Only long-term and systematic spatial development of the territory of the Russian Federation can significantly change the quantitative data of the balance of land fund in the country in general.

As a result of the scanty change in the shares of land in the composition of lands of various categories, we propose that indicators of changes in lands in the composition of various categories of land should be used as quantitative criteria for the development of individual entities of the Russian Federation and individual territories with a special status, primarily those which carry out more intensive economic activities related to spatial development. Probably, the optimal choice would be to use indicators of changes in the land fund in the composition of various categories of land in assessing the development of municipal territories and settlements $[1,7,10]$; also, studying the relationship between the indicators of changes in the land fund and the factors that determine the rate of such changes is important for further research. 
We also calculated the rate of change in the shares of different lands from the area of lands of different categories $V_{\mathrm{ch}} \%$ /year, for 2011-2017, by formula (1) (Table 3).

$$
V_{\mathrm{ch}}=\left(D^{t 2}-D^{t 1}\right) /\left(t^{2}-t^{1}\right)
$$

Where $D^{t 2}$ and $D^{t 1}$ are the share of land from the area of land of a certain category, respectively, for the next and previous dates, $\% ; t^{2}$ and $t_{1}$ are next and previous dates, year, respectively.

Positive values of $V_{\mathrm{ch}}$ correspond to an increase in the share of land in the composition of lands of various categories, and negative values correspond to a decrease.

We propose to use this simple but reliable indicator as an integrating one for assessing the development and ranking of territories of the same level in the presence of information for the same period.

Table 3. Rates of changes in the shares of different lands from areas of lands of different categories (\%/year)

\begin{tabular}{|l|l|c|c|c|c|}
\hline From areas of lands of & $\begin{array}{l}\text { Agricultural } \\
\text { lands }\end{array}$ & $\begin{array}{l}\text { Forestla } \\
\text { nds }\end{array}$ & $\begin{array}{l}\text { Building } \\
\text { lands }\end{array}$ & Roads & $\begin{array}{l}\text { Disturbe } \\
\text { d lands }\end{array}$ \\
\hline settlements & $0.03 \uparrow$ & const & $0.06 \uparrow$ & $-0.05 \downarrow$ & const \\
\hline $\begin{array}{l}\text { industrial and other special } \\
\text { purposes }\end{array}$ & $0.03 \uparrow$ & $-0.09 \downarrow$ & $0.06 \uparrow$ & $-0.03 \downarrow$ & $0.04 \uparrow$ \\
\hline
\end{tabular}

In 2011-2017, the share of settlement lands in the total land fund in the Russian Federation increased from $1.15 \%$ to $1.19 \%$, industrial and other special-purpose lands from $0.99 \%$ to $1.02 \%$, which corresponds to modern Russian ideas about the spatial, but extensive, development of territories.

An informative indicator of changes in the balance of the land fund is a rather paradoxical increase in the share of agricultural land in the composition of lands of both considered categories. This is due to both the absolute increase in agricultural land and a decrease in agricultural land in the land fund of the Russian Federation. The inclusion of the territory of Crimea, which is rich in agricultural lands, into the Russian Federation has played a certain role. However, this fact testifies not so much to the development of lands in both considered categories as to their degradation.

The share of forest land has slightly but clearly decreased in the composition of industrial land. This shows that the "source" of new farming lands for agricultural land is forest land (permissible trend subject to modern conditions). The loss of forest lands from the industrial lands is relative (due to a more significant increase in the area of the latter); in absolute terms, there is a small increase in forestlands in this category of lands, a decrease of which, yet-to-be-observed, would be environmentally unreasonable.

The share of building land has slightly increased in the composition of settlement and industrial lands, while the share of land under roads has decreased. This fact testifies to the unbalanced development of these land categories. Also, the share of disturbed lands has slightly increased in the composition of industrial lands, while not decreasing in other categories of lands, which confirms the well-known fact of insufficient land reclamation.

\section{Conclusions}

1) The spatial development of the territory of the Russian Federation can be diagnosed by calculating the environment-forming potential, which functionally depends on the balance of the land fund in a particular territory. Active indicators, namely the shares of different types of land in the composition of certain land categories from the total area of a certain land category should be considered a priority.

2) Indicators of changes in the land fund are more appropriate for assessing the 
development of municipal territories and settlements with more intensive economic activities related to spatial development.

3) Rate of changes in the shares of different lands from areas of lands of different categories, \%/year, is proposed to be used as an integrating estimated indicator for ranking territories by their spatial development.

4) In 2011-2017, the share of settlement lands in the total land fund in the Russian Federation increased from $1.15 \%$ to $1.19 \%$, industrial and other special-purpose lands from $0.99 \%$ to $1.02 \%$, which corresponds to the extensive spatial development of territories.

5) In the same period, the share of agricultural land in the Russian Federation gradually increased in the composition of lands of both considered categories at a rate of $0.03 \%$ year, which indicates the degradation of these lands.

6) Industrial lands. Here the share of forest lands has slightly decreased (-0.09\%/year). The latter became the basis for the formation of new farmland in agricultural lands. There is no reduction of forest lands in settlement and industrial lands in absolute values.

7) Settlement and industrial lands. Here, the share of building land has slightly increased $(0.06 \% /$ year), while the share of land under roads has decreased (from -0.03 to $0.05 \% /$ year), which indicates an unbalanced development of both categories of land. The share of disturbed lands $(0.04 \% / y e a r)$ in the composition of industrial lands has increased, while not decreasing in settlement lands, which confirms the well-known fact of insufficient land reclamation.

\section{Acknowledgments}

The article was performed according to the state order of the Ministry of Education of Russia No. 0708-2020-0001.

\section{References}

1. A.P. Sizov, Geodesy and Cartography, 6, 43 (2018)

2. O.B. Mezenina, Moscow economic journal, 3, 17 (2019)

3. A.N. Strebkova, Young scientist, 47, 293 (2018), https://moluch.ru/

4. Town-planning code of the Russian Federation of 29.12.2004 No. 190-FL, www.consultant.ru/

5. The European regional/spatial planning charter: adopted at the VI Conference of Ministers for Spatial Planning (CEMAT), Torremolinos, Spain 20.05.1983, https://rm.coe.int/; http://vasilievaa.narod.ru/

6. E.A.Karfidova, A.P.Sizov, Reading memories Sergeyev. Engineering Geology and geoecology. Fundamental problems and applied problems, Anniversary conference dedicated to the 25th anniversary of the IGE RAS (2016)

7. V.V. Abrosimov, E.I. Avrunyov, O.M. Antonova, S.A. Atamanov, I.A. Basova, Selected problems and future issues of land management, cadastre, and territory development (2018)

8. A.P.Sizov, Geodesy and Cartography, 80(10), 55 (2019)

9. Data on availability and distribution of lands in the Russian Federation for 01.01.2012; 01.01.2016; 01.01.2018, https://www.rosreestr.ru/

10. S.A. Lipsky, Legal support of land supervision (control) and monitoring of land, 140 (2018) 